UDC 821.163.41-14.09 Tadić N.

https://doi.org/10.18485/ms_zmskij.2021.69.1.12

Др Јелена С. Младеновић

\title{
ПЕСНИЧКИ СВЕТ НОВИЦЕ ТАДИЋА У ОГЛЕДАЛУ МАЛДОРОРОВИХ ПЕВАЪА
}

Откривајући сродности међу фикционалним световима и богатим бестијаријумима двојице аутора, Лотреамона и Новице Тадића, у овом раду настојимо да сагледамо вишеструке могућности повезивања како њихових ауторских поетика, пониклих на европској романтичарској и традицији савременог српског песништва, тако и личних песничких развоја. Код обојице аутора се у каснијој фази стварања може уочити интригантан заокрет и промена односа према представљеној тематици. Повлачећи линију сродства између временски удаљених поетика европског романтичарског и савременог српског песништва, у текстовима двојице аутора уочавају се дезинтеграције доминантних уметничких парадигми и најављују њихове смене новим.

Кључне речи: бестијаријум, романтизам, савремена поезија, Лотреамон, Новица Тадић.

1. Увод. Уочавање сличности између романтичарског ствараоца познатог под псеудонимом Лотреамон и Новице Тадића може бити од великог значаја за разумевање поетике овог савременог српског песника који је стварао у последњој четвртини 20. и првој деценији 21. века, али и за додатно указивање на утицај чувених Малgорорових иеевања (1868). ${ }^{1}$ Вишеструке сродности стваралаштва ове двојице аутора огледају се најпре у присуству веома раскошних бестијаријума, али и у принципима компоновања песничких слика и описа у складу са начелима која ће прокламовати и баштинити

${ }^{1}$ Исидор Дикас (1846-1870) писац је Маляорорових иевања оg ірофа Лойреамона и две свеске Поезије. Рођен у Монтевидеу, живот је провео у Паризу, где је и умро у 24. години. Ужасавао се присуства других људи и није познато да је имао пријатеља или жена. Ова „прва андерграунд књига““ у историји литературе (РигонАт и ВоглАР 1990: 260) може се читати и као „[...] кошмар болесног, туберкулозног младића, у добу када је умирање од туберкулозе била тортура која је до последњег даха остављала, свирепо живу, жељу за животом“ (МАрић 1964: 9). 
надреалистичка поетика, потом у поштовању принципа временске симултаности, односно синхроницитета, до паралеле између Малдорора као типичног романтичарског хероја и Тадићевог преображеног отпадника, „хришћанина у граду“ (ТАдић 2012в: 206). Реалност зла, агресивност и свирепост, опсесивне су теме обојице аутора, као и истицање језовите природе смеха, мада се однос према приказаном унеколико разликује.

Поред тога, као најзанимљиви, издваја се проблем заокрета који је науци о књижевности задавао највише мука када је у питању стваралаштво обојице аутора. Наиме, након објаве рата Богу у Маляороровим иевањима, Исидор Дикас одлучује да опева само наду и мир, док Тадић, после брижљиве изградње демонизованог песничког света и бласфемичног односа према религиозном тематском комплексу, у каснијој фази стварања проговара у хришћанском покајном тону. Проблем Бога (и безбожништва) веома је комплексан код обојице стваралаца, а наша хипотеза је да се он у обема поетикама може објаснити присуством гностичке визије света, те постојањем Демијурга, другог Бога.

Намера нам је да посредством уочавања сродности са романтичарским претходником, осветлимо природу Тадићеве поетике, утицај Малgорорових $\bar{u} е в а њ a$, па и могуће заједничко порекло имагинације двојице аутора. Указујући на уметничку сродност хронолошки удаљених стваралаца, извлачи се посебна линија ненаметнутог сродства и успоставља лук од романтизма преко надреализма до савремене књижевности високог модернизма, односно постмодернизма. У текстовима двојице временски удаљених песника, читају се дезинтеграције једних уметничких парадигми и њихове смене новим.

2. ПАРАЛЕЛЕ ИЗМЕЂУ МАЛДОРОРОВИХ ПЕВАЊА И ТАДИЋЕВЕ ПОЕЗИЈЕ - БЕСТИЈАРијуми. Необична заједничка особина ове двојице аутора огледа се најпре у педантној изградњи бестијаријума. Лотреамонов хербаријум броји свега три-четири биљке, али се зато јавља раскошни бестијаријум - у првобитном, римском смислу, у смислу средњовековне симболике, као и у модерном, где су животиње симболи необузданих агресивних нагона у човеку (МАрић 1964: 19). Како ће то бити касније и у Тадићевој поезији, бестијаријум симболизује све негативно и зло:

„Та поезија канџи, тентакула, чељусти, двоструко је деструктивна, она је садистичко разарање света и мазохистичко саморазарање, бласфемија из чежње за немогућом чистотом. Та апокалиптична визија света је свакако најаутентичнији вид Лотреамонове поезије, и најоригиналнији. Немогуће је било дати израз таквом психичком паклу ако се није доживео“ (МАрић 1964: 19). ${ }^{2}$

2 Говорећи о Апокалипси, Д. Х. Лоренс истиче да је: „[...] њена раскошна сликовитост одвратна [...] због потпуног одсуства природности“ (2009: 12), какву често можемо уочити и у Лотреамоновим опсима. 
Код Лотреамона су животиње показане кроз своје агресивне функције. Његова бића уједају, никада не спавају и никада нису сита (БАшлАР 2019: 8). Башлар је у Малgороровим иеванима избројао 185 врста животиња, од којих су неке чисто књижевни симболи, као и 435 референци на животињски свет. Оне се увек појављују кроз неки упечатљив детаљ - као смрдљиве мачке Каменитих брда, курјак који бљује пера или у виду митског бића, змаја са беличастим крилима, челичних ребара, чије тело „почиње главом тигра а завршава се дугим змијским репом“(ЛотРеАмон 1990: 125). Гротескна композиција њихових тела допуњена је непрекидном активношћу угрожавања коју предано изводе, а што ће касније користити и надреалисти када буду ишли Лотреамоновим стопама и прелазили из домена слике у домен акције (БАшлАР 2019: 53). Анимализовани живот у Малgороровим иевағима позадина је и за приказивање човека као надживотиње која има сву анималност на располагању (БАшлАР 2019: 16). Човек проширује границе животињског јер за разлику од њих, бива способан за безразложни злочин. Лотреамонове животиње као средства за извршење „злочина“ користе зубе, рогове, кљове, пијавке, кљунове, жаоке (отров), док се као посебно важни у сликама прождирања, издвајају зуб, вилица и кљун као доминантни симболи анимализма и чисте воље (БАшлАР 2019: 19-21). Посебну пажњу Лотреамону заокупља вашка. Ситна животиња, инсект који воли крв, био би у стању да згњечи људе за трен само када би неком силом могао да постане велики. ${ }^{3}$

Овакав вид појављивања животињских бића, на трагу апокалиптичких призора, одговараће и Тадићевом песничком универзуму. У његовој поезији, која обилује тек нешто мањим бројем животињских врста, оне се појављују са сличним функцијама, о чему можемо читати најјасније у песми Роgитељљ:

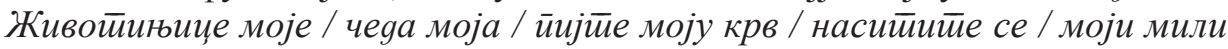
(ТАдић 2012д: 75). Осим тога, пронаћи ћемо и тотемистичке елементе, нарочито у адорацији одређених животиња, као и у присуству духа у њима самима. Демонизација се у Тадићевој поезији спроводи најчешће као вид анимализације, јер готово сви демони имају животињске елементе. Шире гледано, присуство свих бића, било да су животињска или нека друга, застрашујуће је и угрожавајуће, док предност имају птице и птицолика бића (ТЕРЕФ 2009: $\mathrm{VI})$, посебно кокошка као злокобна творевина или архетип напада.

Најпре ћемо у песми Из лог̆ (ТАдић 2012а: 219) уочити да је читав овај свет виђен као велико животињско станиште. И док Тамни пењач као доминантан лик из прве Тадићеве збирке, Присусиива (1974), није у потпуности

${ }^{3}$ Романтичарски песник веома је привржен бићима која сисају. Утваре сисања су андрогине, а таква је и хоботница коју Малдорор на почетку зазива, док се на крају у њу и са̂м претвара: „О хоботнице свилена погледа, ти, чија је душа нераздвојива од моје; ти, најлепша од свих бића на земљи; ти, која управљаш сарајем од четиристо пијавки [...]“ (ЛотРЕАмон 1990: 19). Крилате хоботнице подсећају на гавранове, али код Лотреамона има много мање птица него што ће их бити код Тадића, док је много већа фасцинација воденим светом, те је међу рибама доминантна крволочна ајкула. 
анимализован, мада има неких животињских карактеристика, убрзо се појављује читав низ животиња или бића које имају животињске делове 4 . Њихов број је толико велики да можемо саставити каталог који подсећа на средњовековне бестијаријуме.

Што се птица тиче, јавља се неколико различитих врста. Најпре су ту вране (Вилине воgе, ТАдић 2012а: 130) вранино гнездо, вранина кћи (Док не заруgи зора, ТАдић 2012а: 243), беле вране (Мейлица 50, ТАдић 2012б: 20),

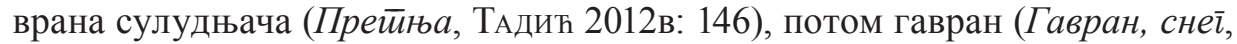
ТАдић 2012a: 144; ТАдић 2012г: 222) који представља небеског чиновника, а појављује се и као гностички симбол у разрачунавању са хришћанским голубом, голубови (Шубара, іолубови, ТАдић 2012б: 32), свраке (Сврака моја, ТАдић 2012а: 202), совуљаге (Црна миса, ТАдић 2012а: 247), несит тј. пеликан (ТАдић 2012б: 162). Механички славуј (ТАдић 2012а: 176) везан је за романтичарску гротеску хофмановског типа и процес аутоматизације, те је демонизација извршена посредством механизације, као и код механичке буљине (Из зияа, ТАдић 2012а: 192). Поред Огњене кокоши, ту су и петлови (Без наслова, ТАдић 2012б: 74), чапља (ТАдић 2012б: 56), црни пернати кум (Пер-

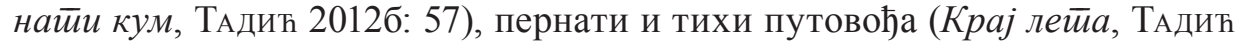
2012г: 43), црвенорепа птица (Уљез, ТАдић 2012в: 37), паун (Прейъа, ТАдић 2012в: 146), подземни јастреб (ТАдић 2012г: 231), друшкан кљукани јастреб, тетреб бубојед (ТАдић 2012б:22), риђе тигрице (Иіллие, ТАдић 2012г: 78), кос (Крчма, калај, ТАдић 2012б: 40), црни кос (Враї врщиља, ТАдић 2012г: 239), црвенорепа птица (Уљез, ТАдић 2012в: 37), али и птицолики створ који је мешавина птице, гуштера и човека (ТАдић 2012г: 245).

Од зглавкара и инсеката, поред Бога који је у једном тренутку приказан

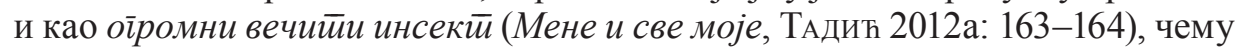
ћемо се вратити касније, појављује се буба као општи појам за различите

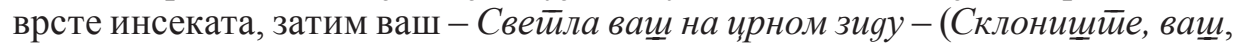
ТАдић 2012б: 149), стидне ваши (ТАдић 2012б: 21), риђобради човек-ваш (ТАдић 2012в: 20), потом мољац (Тещкоћа, ТАдић 2012а: 157) са хиљаду радних усница, пипака, сечива, рила, крилаца. Ту су и друге различите бубе и стоноге (ТАдић 2012а: 82), крпељи (Криеељ иㅡо се качи и лейи за мене, ТАдић 2012б: 159), два стршљена (ТАдић 2012б: 88), бубица и Света пчела (Та бубица, ТАдић 2012д: 102), лептир (ТАдић 2012д: 74), стоноге, паук (Исйовар $y \bar{\imath}$ sa, мака, ТАдић 2012б: 38), црвени скакавац (ТАдић 2012а: 154, 157). У песми

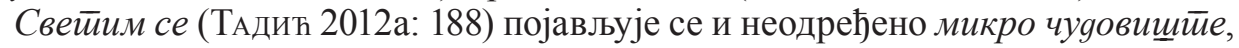

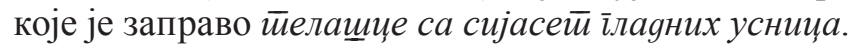

4 У средњем веку нарочито долази до коришћења симболичких потенцијала животињских ликова како би човекова спољашњост могла да ослика његову унутрашњост. Средњи век је доба тријумфа демонских сила, веровања у демоне и свеприсутност зла (ХАРФАм 2004: 77), које се манифестује кроз ружно. И ову традицију Тадић обнавља, мада се нигде аутопоетички о томе не оглашава. Ипак, целокупна његова поетика и есетика, вишеструко су везане за средњовековну и византијску. 
Глодари су, такође, многобројни станари Тадићевог бестијаријума. Вероватно најпознатији је глодар светих списа (Изgахнуо у Беоїраgу, ТАдић 2012г: 237). Демонизована је веверица, а веза која посредује њеној демонизацији успостављена је на основу риђе, ђаволске боје. Цела Тадићева „жгадија“ обухвата и кртице, зечице, јазавце (Прозлио сам се ирозлио, ТАдић

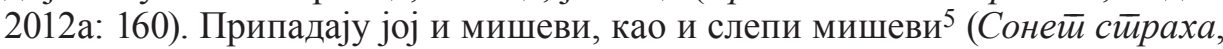
ТАдић 2012а: 162; Дувачи, ноћна зайовести, ТАдић 2012б: 94), пацов подрумар (ТАдић 2012б: 22), пацов (ТАдић 2012б: 162), пацов као седми брат (Сеgми

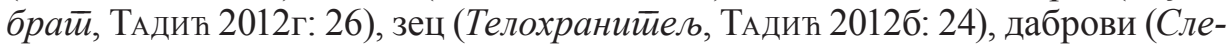
йаu, ТАдић 2012б: 34), твор (Коюски щуусиер, ТАдић 2012б: 219), куна (Дощао је из далине, ТАдић 2012д: 122).

Од осталих звери и зверски обликованих животиња, треба поменути јагуаре, доге (Прекомерна је моја срећа, ТАдић 2012б: 10), жуте псе (Убице се сунчају, ТАдић 2012б: 11), прасца, лисицу, којота (Јављају ми из иенитрале, ТАдић 2012б:14), хијене (Неко ми у сну дощайну, ТАдић 2012г: 15), змијицу (Превлас $\bar{u}$, ТАдић 2012г: 23; ТАдић 2012д: 89), велику жабу (ТАдић 2012г: 223), водену алу (ТАдић 2012б: 86), јелена (Мисиеер, со, ТАдић 2012б: 100), а блиска им је чак и домаћа мачка (Мачка, ТАдић 2012г: 41). ${ }^{6}$

Крилатост, као животињска особина, трансформише се у демонску када се крила додају људима - крилайи некакви љуяи (Јуйро, маїла, ТАдић 2012б: 220). О посебном месту које добијају крилате животиње и крилати демони казује и читав циклус Летиачи на слову из збирке Окриље: Соко, Кобац, Детлић, Јарац, Мува, Блавор, Сврака. Како су све животиње обједињене насловом „летачи“, а како све уистину то нису, видимо да Тадић летење сматра искључиво демонским својством које се приписује демонима и приближава се смислу лета у Маляороровим иеванима, где смо приметили да је сам процес летења важнији од врсте птице која га изводи.

Као посебну животињу Тадићевог бестијаријума, можемо издвојити змију чије су везе са гностичким учењима веома тесне. Иако је реч о симболу који је присутан и у хришћанству, овде је његова симболика померена у односу на званично хришћанско учење. Најчешће се представља у облику уробороса, змије која прождире сопствени реп, што симболизује принцип да су све ствари једно, да оне настају из Једног и да ће се вратити Једном - hen to pan (све је јеgно) $)^{7}$. Тај симбол обухвата идеју кретања, континуитета

5 За Кајзера је слепи миш прави пример гротескне животиње (2004: 256).

${ }^{6}$ Јагње (Песма јайњеш̄y, ТАдић 2012а: 207) је посебна врста животиње која функционише као амбивалентни симбол, са основом у хришћанској симболици животиње-жртве.

${ }^{7}$ Као и стоици, и гностици су користили алегоријски метод излагања и показивали презир према стварности, бавећи се искључиво симболичким значењима истина (ШеПАРд 1986: 122). Многе од гностичких симбола су усвојили и алхемичари (Хермес-Тот), а уроборос је свакако један од њих. Код Вавилоњана и Халдејаца представљена је како опасује небо док гризе свој реп, али је њено порекло од сунца-змије из феничанске традиције. Код старих Египћана, Апофис има главну улогу и показује да је он први кнез таме, као валенција моћи, против кога је кнез светлости Ре (ГерьРАн-ШевАлије 2004: 1106). 
и самооплодње, и представља вечно понављање (ГЕРБРАН - ШЕвАлије 2004: 1103). Истовремено означава спајање хтонског света, који симболизује зми$\mathrm{ja}, \mathrm{c} \mathrm{небеским,} \mathrm{који} \mathrm{означава} \mathrm{кружница} \mathrm{и} \mathrm{одражава} \mathrm{основни} \mathrm{дуалистички}$ принцип јединства супротности. За разлику од хришћанске традиције у којој је змија главни „кривац“ за изгнанство људи из раја, код гностика, она је истовремено и савезница људима, али и симбол божанске мудрости (ПЕЈГЛЕС 1981: 16).

У Тадићевој поезији се овај мистични и гностички симбол налази спорадично, али то не умањује значај његовог присуства, а посебно његово значење које може и одступати од оног које имају остале животиње бестијаријума. Већ у првој збирци, налазимо префигурацију уробороса: $y$ уілу извезена риба / чврстио за рей ухваћена (Сйолњак, ТАдић 2012а: 41). Модификујући и поигравајући се истовремено хришћанском симболиком рибе, као и њеном фолклорном појавношћу кад преузима готову слику из народне брзалице „Риба риби гризе реп“, Тадић обликује аутентичног уробороса, који сведочи о изобличености овога света, дифузном мешању симболике и значењских путева и исхода, рибе као хришћанског симбола и змије/уробороса као гностичког симбола: као да хришћанство само себе поново мора родити. Тадић креће од ихтиса, симбола који је као акроним означавао Исуса Христа. Много пре појаве хришћанства, риба је већ имала своје мистично значење у већини медитеранских, али и других култова. Њена симболика је разнолика: у већини случајева своди се на плодност као небески благослов и давање живота, што због чињенице да живи у води која је давалац живота, што због великог броја јајашца која су, сама по себи, симбол живота и плодности.

У песми Уробор, лайице (ТАдић 2012б: 165), директно се упућује на гностички симбол уробороса, али он сада поприма изобличене демонске карактеристике, као и у песми Изложба (ТАдић 2012г: 42):

\section{Неко нейознайо чудовищйе на једној нози стиоји савијајући врх рейа у усйа.}

Иако много животиња Тадићевог бестијаријума јесу активни чиниоци зла и врше функцију демонизације стварности, то не искључује њихово појављивање у другим, симболичким и алегоријским функцијама, те Тадићев песнички свет често подсећа на средњовековни Фисиолої. За наше истраживање је важно учити и то да је у науци „било доста речи о гностичком утицају на алегоријски симболизам Фисиолоїа“ (ЛАзић 1989: 12). Посебно је наглашаван утицај гностичког пантеистичког учења о присуству божанског духа у целокупном материјалном свету, односно о могућности психичког живота биљака, животиња и минерала (ЛАзић 1989: 12). Поред алегоријских и симболичких потенцијала који су карактеристични и за Тадићеву поезију, анимализација представља и стилски израз обликовања демонског садржаја. У том случају, животиње су посредници деловања де- 
монских сила или репрезенти зла. Могу бити и маске за људске особине, али и тада опет посредно представљају различите облике злог понашања.

Што се тиче самог гротескног моделовања бића и технике спајања делова и код Тадића и код Лотреамона, још једном можемо уочити повезаност са $\Phi u$ сиолоїом и бићима попут кентаура и сирена: „Сирене су пола људи а пола гуске, инокентаври су пола људи пола мазге. Тако је и сваки човек двоједушан, несавршен је на свим путевима својим. [...] разарају добре обичаје злим беседама“" (Фисиолог 1989: 36). Још упечатљивији је пример мраволава: „Предњи део лављи, а задњи мравињи. Отац његов је телоједац, мати, пак, сочивоједац. А када рађа мраволавчића, рађа га са две природе - не може да једе меса, због мајчине природе, а нити сочива ради очеве. И угине због тога што нема хране. Тако и сваки човек двоједушан недовршен је у свим путевима својим. Јер не можеш рећи и да и не, као и не и да, као што рече сам Господ Исус Христос Син Божији и Слово божије“ (Фисиолог 1989: 40).

Код обојице аутора се налазе необична човеколика бића са животињским деловима, која имају своје падане у ликовим Бошових сликарских фантазмагорија: „[...] видео како по мору плива, широких пачијих стопала уместо руку и ногу, с великим леђним перајем, сразмерно исто толико дугим и оштрим као у делфина, неко људско биће снашних мишића која су читава јата риба“" (ЛотРЕАмон 1990: 171). Код Тадића су бизарни спојеви остварени у неологизмима, полусложеницама: жилет-језик, сумрак-жеље, бог-кртица, врата-уста, собичак-јаје, жлезда-звезда, руке-полипи, пламен-крило, уд-фрулица, цурица-цуцлица, пудер-речи, човек-ваш, гоблен-брбљарија, флаше-девице, левак-увце, беба-пепељара, клозет-мама или у синтагматским спојевима: „очешљано огледало“, „умрли колибри“, „моћан и дугореп црни чешаљ“, „уснице дубинског сунђера“, „рукописи са зглавкастим удовима“, „леје засађене људским телима“, „кућа на кокошјим ножицама“, „,овек са копитама изван сандука“" итд.

Паралела се може повући и према функцији животиња у баснама, где су оне представљале личности (fabulae persona). Док у басни животиње раде и говоре као људи, мисли се обратно - људи су животиње. Ова инверзија у потпуности одговара логици песничког света у Тадићевој поезији. Природа Тадићевог песничког света је таква да животиње бивају употребљене и са још једним разлогом: како би се њима указало на људе, управо кроз поменути инверзни принцип. Животиње не представљају неку људску особину и тиме и одређени тип карактера човека или његов поступак, већ идеју да људи јесу животиње, што имплицира њихово нехумано понашање, али и позицију из које се гледа и на људе и на животиње. Господин са кратким ножицама (Сонет̄ на улиии, ТАдић 2012а: 150), лопужа са репином (Лойужа, ТАдић 2012а: 197), човек који носи шакалов шал (Он носи щакалов щиал, ТАдић 2012a: 232) као и полусложенички облик мачке-људи (Високи, у ирним манйилима, ТАдић 2012a: 228), примери су типова појављивања животињских елемената у поменутој функцији. 
Поред гротескног онеобичавања животиња и комбиновања диспаратних делова тела, који користе обојица аутора како би у складу са својим естетикама ружног представили анимализовани свет односно бестијаријум свакодневице, као нарочито занимљив се издваја однос према инсекту, односно малом бићу жељном контроле, чији зверски апетити надмашују животињске громаде. О њиховој неумољивости читамо у Малgороровим иеввағима: „Слон се може помиловати. Уш не“ (ЛотреАмон 1990: 75). Инсект код обојице аутора може заузети божанско место и преузети његову улогу:

„Постоји један инсект што га људи хране својом крвљу. Они му ништа не дугују; али страхују од њега [...] И треба само видети како га људи поштују и окружују га неком пасјом понизношћу, како га уздижу изнад свих осталих животињских створова. Људи су жртвовали главе за његов престо [...] Та ваш је излегла десетине драгоцених гњида, које је грејала својим материнским крилима на вашим косама, исушеним халапљивим сисањем ових опасних уљеза [...] Порашће толико да ћете то осетити, по њиховим канџама и сисаљкама““(ЛотреАмон 1990: 73, 74).

Код Тадића у песми Мене и све моје (ТАдић 2012а: 163-164) инсект добија неприкосновено место у универзуму:

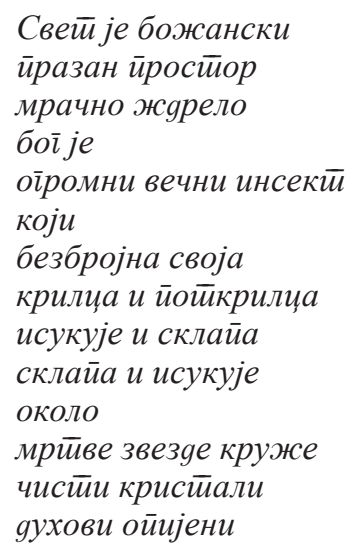

Лотреамонова „божанска жаба“ слична је Тадићевом божанском инсекту, с тим што је Лотреамнов позив на бунт против таквог поретка и безобличног крволочног идола (ЛотРЕАмон 1990: 76) експлицитан, док код Тадића постоји прећутно мирење са поретком: „Докле ћеш чувати црвљиви култ тог бога, равнодушног према твојим молитвама и великодушним понудама који му приносиш на жртву у знак испаштања (ЛотРЕАмОН 1990: 75).“ Тадићев демон кезило са својим кезилићима, о којима ће посебно бити речи, такође функционише аналогно поменутом Лотреамоновом инсекту. Кезилићи се и сами понашају попут ваши - завлаче се у рубове, шавове, имају псеће кевтаве губице и у непрекидној су акцији. 
Дехуманизација, одсуство емпатије и са њом сплетена иронија прецизно маркирају свет Малgорорових йевања:

„Човек и ја, затворени у тамницу свог разума, као језеро у обруч коралних острва, уместо да ујединимо своје узајамне снаге како бисмо се одбранили од случаја и недаћа, ми се удаљујемо, дрхтећи од мржње, и крећемо супротним правцима, као да смо ранили један другог љутом камом! [...] два пријатеља који упорно настоје да се униште - каква драма!“” (ЛотРЕАМон 1990: 147).

У складу са представљеним принципима анимализације, увиђамо да је реч о посебно схваћеном насиљу:

„То чисто насиље није људско; приписати му људско обличје значило би успорити га, одложити га, образложити га. Ако би се у основу тог насиља поставила каква идеја, освета, мржња, оно би изгубило своју тренутну, неоспорну омамљеност, свој крик. [...] Док се животињско насиље спроводи без одлагања, злочиначки искрено, насиље против детета биће зналачки лицемерно. Лотреамон ће укључити лаж у насиље. Лаж је људско обележје првог реда. Како Велс каже, животињи су лажни поступци страни“ (БАшлАР 2019: 11, 39).

Убијање и мучење у Малgороровим иеевањима врши се из чистог задовољства, што појачава казивање у првом лицу једнине:

„Прво би му прождрао главу, ноге и руке, а најзад труп, све док не би од њега ништа остало; јер он је крцкао и кости. [...] Ја вас мучим из чистог задовољства. [...] Ово ми убиство није причинило толико задовољства колико би се могло очекивати; а, тачно говорећи, то је било само зато што сам се већ био заситио тог вечног убијања, тако да сам сад то радио из чисте навике, коју човек не може избећи, но која доноси само незнатно уживање“ (ЛотрЕАмон 1990: 71, 97).

Тако и Тадићев универзум познаје једино крвнике, лажна пријатељства и медвеђе услуге, и до те мере редукован емоционални регистар који не бележи друга осећања мимо страха и стрепње. Ту бисмо издвојили песму о убиству, Цииееле, сан (ТАдић 2012а: 219). Песнички субјект мучи и убија девојчицу након одласка у биоскоп, те можемо приметити инспирацију Малgороровим иевањима, али и литературом Готфрида Бена и Едгара Алана Поа. Злочин је описан и у песми Биоїрафија (ТАдић 2012в: 153), која се лако уклапа у корпус песама о репресијама друштвене стварности, где полицајци, или „људи са оскудним биографијама“, батинају.

3. СинХРоницитети. Имајући у виду временску симултаност, односно синхроницитет, опет уочавамо велику подударност у делима двојице писаца. „Свака сцена у Малдорору је непосредно доживљена када је и замишљена. 
Речена у граматичком презенсу, најчешће као нешто што се збива када се о томе прича, или у имперфекту који није враћање у прошлост, већ евокација, актуализирање нечег што је у трајном постојању“ (МАрић 1964: 21). Вечити трајни презент имамо и код Тадића: утисак да се све збива у часу када се о томе говори као и да тај час не пролази. Трајање продужава ужас у делу обојице аутора. Код Тадића ће садашњост некада бити додатно појачана кроз укидање временске перспективе, што се на синтаксичком плану испољава кроз одсуство предиката, односно глагола у личном глаголском облику, али се осећај непрекидности радње постиже присуством од глагола изведених именица које оначавају делатне субјекте. Такав пример проналазимо управо у песми Кезилићи (ТАдић 2012а: 77), у деловању поменутих злих бића штеточина. Песма је организована као опис, без глагола којим би се означила радња, стање или збивање, а заправо је читава песма „радња“. Опис је дат тако да се види шта кезилићи раде. Кезилићи су сведени на телесно: одређује их вештачки зли осмех, као и балаве губице и разроки језици. Они су иверје похотно, сечива, сисала, лизала, мљацкала, кусала, телоточци и растакала, клапкала. Њихово је порекло змијско (разроки језици), а крију се на местима где и ваши (у порубима и шавовима). Ситни демони сведени су само на глаголе прождирања. Они су истовремено и паразити и отпадници (иверје), чак и када нису посебно именовани (Дремеж, ТАдић 2012а: 78). Поред тога што су њихови називи најчешће у деминутивима, такви су и делови њихових тела, па скакутани имају трбушчиће, ножице и ручице $(y$ лейьиковиу, ТАдит 2012а: 79).

Битно је подвући значење тог презента који делује изоловано и од прошлости и од будућности. Не може се веровати у исход било какве временске линеарности и протока времена, јер је субјекат ужлебљен у садашњост догађања вечите страве. У питању је невременска, свевременска или безвременска постојаност, а симултаности сцена доприноси се адекватним избором глаголског времена, најчешће презента или аориста, који као да бришу могућности постојања прошлости и будућности. Пакао садашњости код Новице Тадића ипак трпи преображај, ако имамо у виду целовитост његовог тамног пева, и појављује се визија будућности у оквиру комплекса идеја хришћанског православног спасења, али то не значи да у појединачним песмама не можемо да говоримо о потпуном одсуству временске перспективе.

4. Смех. Једна од каратеристика Тадићевог бестијаријума је та да се он у целости злокобно смеје и да смех нигде нема ослобађајући ефекат. Кроз црни хумор и сардонични смех, подстиче се осећање језовитости. Што се тиче природе смеха код Лотреамона, исто је реч о језовитом и наказном смеху који не познаје друге облике: „Ја, ја не знам да се смејем. И никада нисам знао да се смејем мада сам више пута покушавао да то учиним. Збиља, тешко је научити смејати се. Или, боље, чини ми се да неко осећање одвратности према том гнусном чину представља основно обележје мог карактера“" (ЛотреАмОн 1990: 149). Лотреамон радикално осликава кез, окамењени део осмеха 
који настаје физичким исецањим лица да би се направила жељена гримаса, а као таква она је вид отуђења и дехуманизације код обојице аутора, насупрот идеји да је смех тај који човека одваја од животиње:

[...] имао сам жељу да се смејем као и други; али то чудно подражавање било ми је немогуће. Стога сам узео нож оштра сечива и исекао кожу у пределу где се састају усне. За тренутак ми се учинило да сам постигао свој циљ. Угледао сам у огледалу та уста унакажена по мојој сопственој вољи! Била је то заблуда! Крв која је у млазу текла из посеклина спречавала је, додуше, да јасно разазнам да ли је мој смех био као и у других. Али после неколико тренутака таквог упоређивања, видео сам јасно да мој смех не личи на људски смех, то ће рећи, ја се и нисам смејао (ЛотРеАМОН 1990: 10).

Колико је ипак кез као инверзни облик осмеха битан, казује и једно од главних и аутентичних Тадићевих гротескних бића, већ поменути кезило са својим кезилићима. То је биће сведено да део, и то на уста која су повезана са мотивима прождирања, али која су дематеријализована и претворена у изобличени осмех. Кез означава гримасу, искривљени израз лица, те је Тадићев кезило са својим кезилићима део гротескне карневалске поворке (коjoj недостаје снага препорода) и изражава њен сабласни вид. ${ }^{8}$ Сардонични (или сардонски - risus sardonicus) смех је усиљен и горак, подругљив и пакостан, али значење може упућивати и на грчевито развлачење мишића лица, будући да назив има етимолошку везу са отровном биљком (Sardonia herba), чији је ефекат конзумирања стварање гримасе као код оног ко се злобно смеje. Укочени пакосни смех главни је сигнум Тадићевог песничког универзума.

5. ПоБУНА и МЕСТо БоГА. Извесне, али не и потпуне подударности, можемо повући између централне фигуре, јунака/песничког субјекта Малgорорових йевања и песничких субјеката Тадићеве поезије. Малдорор је типични црни романтични херој који је истовремено и узвишен и јадан, и натприродно моћан али и неснађен и изгубљен у овом свету. Горд је као Сатана и желео би да буде једнак Богу. Малдорор сања о већем непријатељу и зато изазов упућује самом творцу. Иако створен, он ће кроз насиље постати стваралац (БАшлАР 2019: 41) и у томе је сва сврха његовог деловања. „Лудило генија“ (БАшлАР 2019: 43) које карактерише Лотреамона испољава се, дакле, превасходно кроз насиље које је постало вид стварања у вредносно инверзном смислу, а лотреамонизам бива појачан до богохуљења (БАшлАР 2019: 41).

\footnotetext{
${ }^{8}$ Поред кезила и кезилића, овим Тадићевим бићима од којих нека већ и у називу могу носити нешто од гаргантуовско-пантагруеловске глади и могућности прождирања, су и саїраило, ірицкало, мљаикала, кусала, сисала, лизала, клайкала, растиакала и скакуйани.

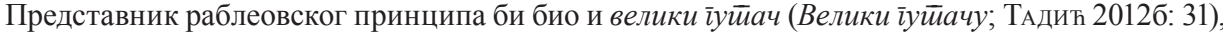
а песнички субјект у складу са њим „умире на сва уста“ (Призивање ноћи; ТАдић 2012а: 127).
} 
Романтични бунтовник против Бога, власти, ауторитета и сваког поретка није на исти начин могао бити остварен у Тадићевој поезији. Али, будући да је реч о песничком универзуму којег одликује вишегласје, на моменте можемо приметити и преобликоване одјеке романтичарског презира и надмоћи. Тадићев бунтовник, „хришћанин у граду“, потоњи „тајни монах“, преображени је отпадник, потукач. Он може да реплицира бунт једино као тиху побуну, кроз преплетене гласове и кроз присуство разлике и дисонантних тонова унутар песничког система доведеног до границе самоукидања која, међутим, никада није пређена.

Главна сличност међу свим отпадницима била би њихово безбожништво 9 Управо тај проблем не може се једноструко и лако решити. О идеји апсолутног безбожништва се у опусима ове двојице писаца не може говорити, јер и код Лотреамона Бог постоји, као што постоји и свет који је он направио. Ни код Тадића место трансценденције никада није било укинуто, али је оно могло бити другачије попуњено, као у песми $У$ фризерском салону:

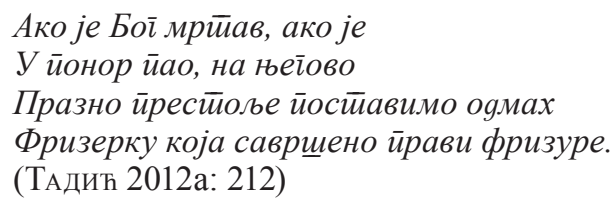

Паралелно, у Малgороровим иеевањима, остварена је субверзивна победа демонског кроз прерушавања у божанске ликове: „Један арханђео који беше сишао с неба носећи поруку Господа, нареди нам да се претворимо у једног јединственог паука и да долазимо сваке ноћи да ти сисамо грло“(ЛоTРЕАМОН 1990: 217-218).

Међутим, Лотреамоново безбожништво не можемо схватити као пуки атеизам, већ га пре посматрати у духу гностичке визије света, која Богу „урачунава“" и присуство зла у свету, односно нужност зла као активног принципа (уп. МАксић 2010). У том смислу је важно уочити елементе дуалистичког гноситичког учења, пре него деловање изворног сатанизма са којим су Малдоророва иеевања често довођена у везу.

Могли бисмо рећи да је Лотреамону блиска Ничеова идеја натчовека који претендује на упражњено место Бога. Колико год антихуманстички био настројен, Малдорор је човек. Ослобођен Бога као и Ничеов натчовек, може се супротставити човеку, будући да припада свету зла којег је направио Створитељ (Демијург), врховни зли или други Бог гностика: „Он (Створитељ, прим. Ј. М.) је у раздртој одежди лежао насред пута. Доња му је усна висила грозно отромбољена; зуби су му били прљави, а прашина се мешала с плавим таласима његове косе. Умртвљено од тешког дремежа, клонуло

${ }^{9}$ Напомињемо да није од пресудног значаја колико се оно тиче самих аутора, већ пре свега текстуалних инстанци - песничког субјекта и наратора. 
на шљунак, његово је тело с муком покушало да се придигне. [...] Био је пијан! Ужасно пијан!“‘(ЛотРЕАмон 1990: 127, 128). У Тадићевој поезији, такође, јасно се издваја присутво два Бога (МлАдЕновић 2018). Његов други Бог (протомајстор, демијург, зли бог...) јавља се као творац материјалног света и својеврстан је метафизички одговор на порекло зла у њему:

\author{
Друіи боже \\ зар ћем се и йи \\ бавитии стиварањем \\ Парампарчад (ТАдић 2012а: 156)
}

Лотреамон је настојао да осветли реалност зла, агресивности и свирепости, изражавајући визију света који је дубоко зашао у сопствено пропадање. Та идеја је кључна и за поетику Новице Тадића. Малдорор је схватио да правде нема и да сваки човек изазива ужас свог ближњег. Човек је зао, али не зна зашто је зао и као да га на то наводи нека виша сила. Као да је узрочник свег тог делиријума зла сам Бог, први садиста, стари крвник и највиши блудник: „Да ли је то лудило моје болесне свести или тајанствени нагон независан од мога разума и сличан нагону орла који раздире свој плен - то што ме је нагнало да извршим овај злочин? У ствари, ја сам патио исто колико и моја жртва!“ (ЛотРЕАмОн 1990: 13) Идеја старог крвника блиска је идеји гностичког злог Бога, Демијурга, који је творац земаљског света, те отуда одговоран и за целокупно зло на њему (ЛАКАРИЈЕР 2001; ПЕЈгЕЛс 2006). Када говори о таквој сили, Лотреамон не говори о Богу, добром Богу, мада му не одриче постојање: „Божанска искра која тиња у нама, која се ретко јавља, тада блесне; али сувише касно! [...] О ти, чије име не желим да поменем на страницама посвећеним светињи злочинства, знам да је твој опроштај бескрајан. Али ја, ја још постојим“ (ЛотреАмон 1990: 14). Његова визија усредсређена је на земаљско зло, чији је творац само један од два бога из дуалистичких религиозних концепата, какав је гностички.

Присуство доброг Бога у оквирима Тадићевог песничког универзума много је јасније у молитвено и плачно интонираним стиховима из касније стваралачке фазе. Иако је Демијург задужен за стварање земаљског света, код Тадића је он метафором обликована песничка слика зла, док је појавно зло последица и људских активности, где се као најстрашнија издваја злоупотреба сопствене слободе. Хришћанска и гностичка визија овде опстају под једним кровом јер причу о целини, мења прича о фрагментима и вишегласју које они стварају.

Код Лотреамона се често може учинити да је једино присутан други Бог, те се отуда лакше остварује могућности везивања Малgорорових иеваға за култ сатанизма. Малдорор, међутим, носи одјек јововске запитаности над божанским делима која нису добра: „Зашто има неправде у божанским одлукама? Да ли је Створитељ безуман; а истовремено најјачи у свом бесу! [...] Видео сам Створитеља како, подстрекавајући своју бескорисну окрутност, 
подмеће пожаре у којима гину старци и деца!““(ЛотреАмон 1990: 42, 54-55). Зато су читава Малgоророва йевањ $а$ његова борба са Богом у овом земаљском свету. Битно је, дакле, још једном истаћи да Бог није укинут и да он „несумњиво постоји, пошто постоји свет који је он створио, и који нико други тако ужасним не би могао створити“" (МАрић 1964: 24). Посебно занимљивим чини нам се и да овде приметимо да је преводилац Малgорорових $\bar{u} е в а љ а$ на српски језик, Данило Киш, и сам гајио особиту наклоност према гностичком учењу у свом приповедном опусу (БЕчЕЈски 2019), те да је побуна оно што ове књижевнике, укључујући и Тадића, повезује. ${ }^{10}$

6. СПОРНИ ЗАОКРЕТ У ЛОТРЕАМОНОВОМ И ТАДИЋЕВОМ ОПУСУ. ЧУвеНИ Заокрет у Тадићевом певању, појављивање покајног тона и хришћанске идеје спасења после исцрпног певања о злу, отворио је многа питања међу тумачима његове поезије, а нарочито после појављивања збирке Нейойребни сайуйници (1999). Сличан заокрет можемо уочити и код далеког романтичарског претка. Најпре је он наговештен у самим Малgороровим иеевањима: „Двадесет страна пред крај, анималних призора готово и да нема: у бестијаријуму се више не појављују нове животиње. Тон постаје мање блистав, и ухо наштимовано на претходна певања већ наслућује како се ближе завршне ноте, да је комплекс размотао своје прстенове“" (БАшлАР 2019: 47), а настављен у потоњем писању. У Поезијама (Преїgовор за јеgну буgућу књиїу) изнесена су фрагментарна разматрања о природи ондашње књижевности. Управо се ово дело Исидора Дикаса узима као кључни елемент који указује на идејну промену у његовом стваралаштву, која је и изазвала извесне недоумице. Већ на самом почетку аутор најављује: „Замењујем тугу храброшћу, сумњу извесношћу, безнађе надом, пакост добротом, кукњаву дужношћу, скептицизам вером, софизме спокојством а охолост скромношћу“ (ЛотРЕАмон 2009: 183). Најважнија промена је призивање наде уместо очајања јер очајање води до општег укидања божанских и друштвених закона, и у теоријску и практичну злобу (ЛотРЕАмон 2009: 188). Почиње да се залаже за одбацивање описивања бола и јасно издваја религиозно место Бога: „Несрећа постаје узвишена само онда када је она дело недокучиве Божје воље“" (ЛотРЕАмон 2009: 190). Некада потпуно посвећен једино описивању зла, сада га радикално одбацује: ,Ја не прихватам зло. Човек је савршен. Душа не умире. Напредак постоји. Добро је неуништиво. Антихристи, пали анђели, вечне муке, религије - све је то само последица сумње“ (ЛотРЕАмон 2009: 193). И док је раније описивао несреће које су изазивале страх, сада се окреће једино идеји среће, не би ли је тако изазвао.

10 Данило Киш упућује на то преимућство гностицизма као начина одвајања од догматичког начина размишљања: „[...] гноса је латентно стање побуне и незадовољства стварањем и светом, поглед на свет и живот, рекао бих биолошка суштина неких сензибилних бића; стога се тај гностички дух одражава кроз векове као латентна побуна, као немирење са устројством света, као хиперсензибилност и луцидност“ (Киш 2006: 117-118). 
Историчари књижевности одгонетали су питање да ли је преокрет у Лотреамоновом певању стварни или привидни (НовАковић 1995: 391). Сретен Марић развија тезу да је Лотреамон из чисто књишког сатанизма прешао у књишки конформизам, а да заправо не знамо чиме је тај прелазак био изазван: „Да ли због фијаска са Певанима, због жеље да што пре стекне име, или због стварног преокрета убеђења, тек неколико месеци касније (после објављивања Певања, прим. Ј. М.), Дикас одједном изјављује да се потпуно одрекао своје прошлости““ (1964: 18).

Надреалисти овај преокрет другачије виде. Утицај који су Малgоророва

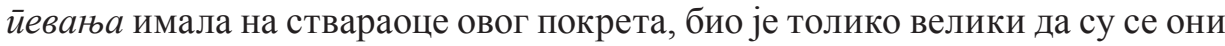
на лик и дело славног романтичара позивали до идолопоклоничких размера. Тако није чудно да је баш Бретон покушавао да оправда тај раскол у Лотреамону и његов готово апсурдан, али свакако изненађујући, чин негације сопственог дела. За Бретона и надреалисте, и такав заокрет израз је бунта: и Лотреамон са̂м се морао окренути против онога што је заступао у Маляороровим иеевањима. Надреалисти су у Лотремону пронашли оно што њихови претходници нису, а то је управо његово величанствено бунтовништво (НовАковић 1995: 372-373): од ослобађања језика до друштвене акције. ${ }^{11}$ Лотреамон доноси ново схватање морала, побуну против свих конвенција, романтичарске традиције, али и цивилизације, хуманости и човека самог: „Моја ће поезија живети само за то да напада свим средствима човека, ту дивљу звер, и Створитеља, који није морао да сазда једног тако бедног црва“ (ЛотреАмон 1990: 58). Лотреамон преиспитује и саме границе испољавања бунта у оквиру књижевности ${ }^{12}$, те отуда у Поезијама бива побуњеник и против себе самог из Малgорорових иеевања. Овакав вид преокрета, подсећа на поступније увођену промену у оквиру Тадићевог песничког опуса, коју не можемо објаснити радикалним бунтом, али свакако променом гласа и увођењем новог тона који разбија монолитност ранијег пева.

7. ЗАКљУчАк. У поетичком смислу, сама Малgоророва иеввања представљају обрачун са тадашњом романтичарском литературом (СтАРовински 1984). Маляоророва йевања представљају довршено дело и приводе крају један период стваралаштва романтизма. Романтизам се осипа и најављује долазак модерне које ће се прокламовати самим чином дезинтеграције, како субјекта тако и света. Отуда у Певањима има и ироније и пародије великих романтичарских мотива. Да је у питању успела пародија види се пре свега у томе што она никако није у првом плану, већ је повучена у позадину.

11 „Лотреамон се појављује као најављивач надреалистичке тежње ка ослобађању језика од његове, строго утилитарне, функције саопштавања и давању аутономије поетском изразу у чијем су слободном функционисању надреалисти оптимистички видели пут ка преображају света“ (НовАковит 1995: 377).

12 Претеривање је оно што одликује Лотреамоново вербално понашање јер у свему што пише има танденцију да пародира или шокира, до самог језика (РиФАтеР 1984: 10). Према Рифатеру, Лотреамонов текст је случај једне „генерализоване катахрезе“ (1984: 27). 
Код Тадића, такође, можемо видети превазилажење поезије високог модернизма, идеје целовитости, и појављивање постмодернистичких тенденција управо кроз фрагментираност и дезинтеграцију, кроз иронију и пародију како митова из литературе, тако и идеолошких митова, као и кроз побуну против догматизма једног система. Преображај властитог тона који је одговарао сликању бестијаријума, и његово удвајање увођењем покајног, молитвеног и плачевног елемента, допринело је полифонијском отварању текста.

Уочена сличност на различитим семантичким нивоима, естетичким и поетичким, иде у прилог тврдњи да се сви изразити ствараоци сами повезују и проналазе своје претходнике и следбенике мимо хронолошких токова историје књижевности. Тадић је на истим местима као и његов далеки песнички предак мењао поетичку парадигму. У низу посебних аспеката њихове подударности, лежи одгонетка о могућем асоцијативном читању историје књижевности, те повезивањима у сродству по избору. И Исидор Дикас и Новица Тадић представљају ауторе који својим делом превазилазе један а уносе други поетички модус. Инспирисани гностичком визијом постанка света и порекла зла у њему, али и самом идејом побуне, што је у крајњој линији и дозволило како промену тона певања, тако и присуство оба тона у целини опуса, ову двојицу песника повезао је и необичан лични преображај. То је можда последња поменута, али вероватно прва карика у ланцу сродности који их повезује.

\section{ИЗВОРИ}

ЛотреАмон. Малуоророва йевања. Београд: Хаос, 1990.

Lotreamon. Sabrana dela: Maldororova pevanja. Poezije. Pisma. Beograd: Utopia, 2009. ТАдић, Новица. Сабране иессме 1. Подгорица: Матица српска-Друштво чланова у Црној Гори (Београд: Службени гласник), 2012а.

ТАдић, Новица. Сабране иессме 2. Подгорица: Матица српска-Друштво чланова у Црној Гори (Београд: Службени гласник), 20126.

ТАдић, Новица. Сабране иессме 3. Подгорица: Матица српска-Друштво чланова у Црној Гори (Београд: Службени гласник), 2012в.

ТАдић, Новица. Сабране иеесме 4. Подгорица: Матица српска-Друштво чланова у Црној Гори (Београд: Службени гласник), 2012г.

ТАдић, Новица. Осйавщйина. Подгорица: Матица српска-Друштво чланова у Црној Гори (Београд: Службени гласник), 2012д.

Фисиолої. Среgњовековни меgииински сйиси: избор. Београд: Просвета - СКЗ, 1989.

\section{ЦИТИРАНА ЛИТЕРАТУРА}

БАшлАР, Гастон. Лойреамон. Београд: Б. Кукић - Чачак: Градац, 2019. 
Бечелски, Мирјана. Данило Киш и гностицизам. Зборник Майище срӣске за књижевност̄ и језик 67/2 (2019): 559-579.

КАјзер, Волфганг. Гройескно у сликарсӣву и йеснищйву. Нови Сад: Светови, 2004. ЛАзић, Милорад. Фисолог у византијској и српској средњовековној књижевности. Фисиолої. Среgњовековни меgицински сйиси: избор. Београд: Просвета - СКЗ, 1989. Лоренс, Д. Х. Айокалийса. Београд: Службени гласник, 2009.

МлАдЕновић, Јелена. Елементи православног и гностичког учења у поезији Новице Тадића. Д. Бојовић (ур.). Визанйијско-словенска чйенија I. Ниш: Центар за византијско-словенске студије Универзитета у Нишу - Међународни центар за православне студије - Центар за црквене студије, 2018, 401-412.

НовАковић, Јелена. Лотреамон у огледалу српског надреализма. Кюижевна истиоpuja 27/97 (1995): 371-393.

РигонАт, Флавио, Иван ВоглАР. Лотреамон (1846-1870). Лотреамон. Малgоророва иевања. Београд: Хаос, 1990, 260-261.

ШЕПАрд, Х. Џ. Гностицизам и алхемија. Граgаu 13/ 71-72 (1986): 117-127.

*

Harfam, Džefri. Groteskno: prvi principi. Polja 49/ 429 (jul-avg. 2004): 49-57.

Kıš, Danilo. Homo poeticus. Beograd: Prosveta, 2006.

LAKARIJER, Žak. Gnostici. Čačak: B. Kukić - Beograd: Umetničko društvo Gradac, 2001. MAKsić, Ivana. Linija otpadništva u francuskoj (post)moderni. Polja 55/ 465 (2010): 114-125. MArić, Sreten. O Lotreamonu. Lotreamon. Sabrana dela. Beograd: Nolit, 1964: 5-28.

Pejgels, Elen. Gnostička jevanđelja, Beograd: Rad, 2006.

Rifater, Majkl. Generisanje Lotreamonovog teksta. Delo XXX/5 (maj 1984): 10-27.

Starobinski, Žan. ...Alterius spectare laborem: Maldoror na obali. Delo XXX/ 5 (maj 1984): $1-9$.

ŠEvalije, Žan, Ален Gerbran. Rečnik simbola. Novi Sad: Stylos - Kiša, 2004.

Teref, Steven. Introduction: The Birdman of Belgrade. Novica Tadić. Assembly. Austin: Host, 2009, i-X.

Dr Jelena S. Mladenović

\section{NOVICA TADIĆ'S POETIC WORLD MIRRORED IN THE SONGS OF MALDOROR}

\section{Sum mary}

By discovering the affinities among fictional worlds and plentiful bestiaries of the two authors, Lautréamont and Novica Tadić, this paper tends to examine multiple prospects of linking both their authorial poetics emerged from the European romantic tradition, as well as the contemporary Serbian poetry, and personal poetic development and geneses. An intriguing turn and a change of attitude towards the subject matter can be 
noticed in the later work of both authors. By drawing the affinity line between the temporally distant poetics of romantic and contemporary Serbian poetry, the desintegrations of the dominant artistic paradigms are noticed, and their alteration with the new ones are signaled.

As primary affinities, we would single out the bestiaries which resemble the medieval Physiologist, the apocalyptic introduction of grotesque creatures, the insistence on aggression and atrocity of the world, the uncanny nature of laughter, principle of synchronicity, as well as the elements of gnostic doctrine.

Универзитет у Нишу

Филозофски факултет

Департман за србистику

jelena.mladenovic@filfak.ni.ac.rs 